\title{
AMAZÔNIA AZUL, DIREITO INTERNACIONAL E PODER MILITAR: UM ENCONTRO NECESSÁRIO PARA O BRASIL DO SÉCULO XXI \\ DOI 10.29327/230731.12.24-2
}

\author{
Nayara Tavares Cardoso ${ }^{1}$ \\ Bianca Pereira Bittencourt ${ }^{2}$
}

Resumo: Em 2004, o Brasil, no âmbito da Organização das Nações Unidas (ONU), submeteu à Comissão de Limites da Plataforma Continental (CLPC), o pedido de extensão dos limites de sua plataforma continental, além das 200 milhas náuticas. Tratase da Amazônia Azul, região maior que a Amazônia Verde e que se encontra distribuída nas regiões Norte e Sudeste/Sul do território nacional. Parte significativa do pleito já foi deferida pela CLPC e novas submissões foram realizadas. Nesse início de século, em que o conflito permanece subjacente na relação entre os Estados, entendemos ser a Amazônia Azul, última fronteira do Brasil, exemplo da necessidade que o País tem de fortalecer seu poder naval, a fim de garantir a soberania na região. O principal objetivo do presente artigo é discutir a importância de se conjugar o Direito e a Força para que - Brasil esteja preparado para defender seus interesses, seja por sua capacidade dissuasória, seja por mecanismos de cooperação, ou pela capacidade militar. Assim, o artigo fundamenta-se em conceitos como oceanopolítica, soberania, direito internacional e poder militar. Por meio de pesquisa bibliográfica e documental, foi possível concluir que poder militar e direito internacional devem estar conjugados na realidade interna e na ação internacional no Brasil do século XXI.

Palavras-chave: Amazônia Azul; Direito Internacional; Poder Naval.

ABSTRACT: In 2004, Brazil, within the scope of the United Nations (UN), submitted to the Commission on the Limits of the Continental Shelf (CLCS), the request to extend the limits of continental shelf, in addition to the 200 nautical miles. This is the Blue Amazon, a region larger than the Green Amazon and which is distributed in the North and Southeast / South regions of the national territory. A significant part of the claim has already been accepted by the CLCS and new submissions were made. In this beginning of the century, when the conflict remains underlying the relationship between States, we understand that the Blue Amazon, Brazil's last frontier, is an example of the need that the country has to strengthen its naval power in order to guarantee sovereignty in the region. The main objective of the present article is to discuss the importance of combining Law and Force, so that Brazil can be prepared to defend its interests, either

\footnotetext{
${ }^{1}$ Nayara Tavares Cardoso possui doutorado em Ciência Política pelo Instituto Universitário de Pesquisas do Rio de Janeiro (Iuperj), mestrado e graduação em Administração. Também possui MBA's em Gestão Universitária e Gestão de Recursos Humanos. É integrante do Grupo de pesquisa Política Externa Brasileira: questões de defesa e segurança na Amazônia Azul; temas de política mundial, da Escola Superior de Guerra (ESG). Membro do ILADISC - Iniciativa Latino Americana de Direito, Sociedade e Cultura. É professora nos cursos de Pós-Graduação (MBA's) IBMEC e IBMEC In Company. É professora da Faculdade Presbiteriana Mackenzie Rio. Foi bolsista do Conselho Nacional de Desenvolvimento Científico e Tecnelógico-CNPq. E-mail: nayaracardoso@ uol.com.br - ORCID: 0000-0001-9499-2976 https://orcid.org/0000-0001-9499-2976.

${ }^{2}$ Bianca Pereira Bittencourt possui pós-doutorado em Ciência Política pelo Instituto Universitário de Pesquisas do Rio de Janeiro (Iuperj) e doutorado em História pela Universidade Federal do Rio de Janeiro. É mestre em Relações Internacionais pela Universidade Federal Fluminense, bacharel e licenciada em História pela Universidade Federal do Rio de Janeiro. Atualmente, é pesquisadora em História na Amazul S.A., atuando em parceira com a ESG, onde lidera o Grupo de pesquisa Política Externa Brasileira: questões de defesa e segurança na Amazônia Azul; temas de política mundial. Desenvolve pesquisas na área de Política Externa Brasileira nas perspectivas de Direitos Humanos, Poder, Segurança Internacional, Defesa.E-mail: bia.pbittencourt@ gmail.com - ORCID: 0000-0002-3526-9849 https://
} 
through its deterrence capacity, through cooperation mechanisms and military capacity. Then, this article is based on concepts such as oceanopolitics, sovereignty, international law and military power. Through bibliographic and documentary research, it was possible to conclude that military power and international law must be combined in the internal reality and in the international action in 21 st century Brazil.

Keywords: Blue Amazon; International Law; Naval Power.

\section{INTRODUÇÃO}

A cooperação e o conflito constituem realidades e, ao mesmo tempo, possibilidades sempre presentes nas relações internacionais. O período pósGuerra Fria, embora tenha marcado o fim do conflito ideológico entre os blocos capitalista e socialista, com a vitória daquele bloco, não necessariamente marcou o fim da preocupação dos Estados com questões como fronteiras físicas, soberania, poder militar (MIYAMOTO, 2003). Embora a tendência, desde o fim do século passado seja a ocorrência de conflitos intraestatais, aqueles de caráter interestatal restam ainda latentes no sistema internacional nesse início de século XXI (NYE Jr., 2009).

De acordo Tereza Cristina Nascimento França, o oceano é veículo e palco de disputas de projeção de poder e o meio ambiente marítimo é o cenário por excelência da Oceanopolítica (FRANÇA, 2012). De acordo com a autora, "o mar carrega em si uma diversidade de temas internacionais por ser uma categoria geográfica entre o espaço e a posição", sendo que "a dinâmica espacial encontra-se na base do esqueleto das Relações Internacionais" (FRANÇA, 2012, p. 64). No que concerne à posição, seu aspecto político atrela o mar ao Estado, o que faz o poder do mar inerente ao seu tamanho. Assim, por exemplo, uma frota marítima tem poder tanto de coerção quanto de destruição à distância.

O Brasil é uma potência média ou emergente 3 ; possui interesses internacionais gerais e mantém visão própria do mundo, além de ser também dono de considerável patrimônio natural que envolve riquezas aquáticas (LAFER, 2001). Desta forma, o País deve estar pronto a defender seus interesses na seara internacional; a posicionar-se de forma autônoma, seja no

\footnotetext{
${ }^{3}$ Cientes da inexistência de uma definição consensual entre os especialistas quanto à nomenclatura potência emergente, ao adotá-la o fazemos com base nos critérios descritos por Maria Regina Soares de Lima e Monica Hirst. Esses critérios, segundo as autoras, englobam os seguintes elementos: a) certa medida de capacidade material que os diferencie dos demais países em desenvolvimento na estratificação internacional; b) especificidades com relação ao desempenho de um papel diferenciado no sistema internacional, ou a suas estratégias internacionais, ou uma medida comportamental; c) indicadores de autopercepção e de reconhecimento dos demais. Cf.: LIMA, Maria Regina Soares de, HIRST, Monica. Brasil, Índia e África do Sul: desafios e oportunidades para novas parcelas. São Paulo: Paz e Terra, 2009, p. 7 .
} 
ambiente cooperativo ou conflituoso. A Amazônia Azul exemplifica esta realidade. Trata-se de uma extensa área marítima, com potencial de riquezas ainda não conhecido, em relação a qual o Brasil busca, junto à Organização das Nações Unidas, o reconhecimento de soberania.

Como nos lembra Celso Lafer, o pacifismo e o respeito ao Direito Internacional são traços característicos da identidade internacional brasileira, traços esses realçados pelo fato de, desde a Guerra da Tríplice Aliança, o País não mais ter-se envolvido diretamente em guerras (LAFER, 2001). De fato, conforme registram os próprios Documentos de Defesa brasileiros, como a Política Nacional de Defesa (PND) e a Estratégia Nacional de Defesa (END), a dissuasão constitui o fio condutor das ações do País no campo da Segurança Internacional e da Defesa. O respeito ao Direito Internacional e a defesa da soberania nacional recebem destaque em semelhante patamar de relevância.

A partir das "Tarefas Básicas do Poder Naval", destaca-se a capacidade da Marinha do Brasil de negar o uso do mar ao inimigo; controlar áreas marítimas; e, especialmente, contribuir para a dissuasão. Mesmo porque, a dissuasão contra qualquer concentração de forças hostis nas águas de interesse nacional constitui "objetivo prioritário da estratégia de segurança marítima" brasileira, conforme estabelecido na PND (BRASIL, PND 2016, p. 26). Como pode ser observado no Documento em tela, "o Brasil privilegia a paz e defende o diálogo e as negociações para a solução de controvérsias entre os Estados" (BRASIL, PND 2016, p. 4). No entanto, nesta mesma Política registra-se que a história demonstra o papel relevante das relações de força no interagir dos Estados. Nesse sentido, são lembradas as palavras do patrono da diplomacia brasileira, o Barão do Rio Branco: "nenhum Estado pode ser pacífico sem ser forte" (BRASIL, END 2016, p. 7).

A presente discussão se justifica por focar a necessidade de o Estado brasileiro investir em poder militar, particularmente no poder der naval, na Marinha do Brasil, no sentido de fortalecer a Defesa. Nessa perspectiva, advogase aqui ser fundamental, indispensável e inadiável aparelhar a referida Força. Desta forma, cabe inserir nessa discussão o PROSUB - Programa de Desenvolvimento de Submarinos -, o qual constitui parte essencial do investimento na expansão do Poder Naval brasileiro para proteger o patrimônio natural e garantir a soberania nacional no mar (BRASIL, Ministério da Defesa, $O$ PROSUB, s/d).

Com base em Jorge Martínez Busch, entende-se Oceanopolítica como "a consideração da existência do oceano no entorno geográfico, e a influência desta sobre as decisões políticas" (BUSCH, 1993, p. 134). Outro conceito basilar para nossa discussão é o de Poder Naval - expressão militar do Poder Nacional -, 
expresso na Doutrina Básica da Marinha do Brasil (BRASIL, 2014). De acordo com a referida fonte, Poder Naval é:

um componente da Expressão do Poder Nacional e integrante do Poder Marítimo, capaz de atuar no mar, nas águas interiores e em certas áreas terrestres limitadas de interesses para as operações navais, incluindo o espaço aéreo subjacente visando a contribuir para a conquista dos objetivos identificados na Política Nacional de Defesa (PND) e na Política Militar de Defesa (PMD).

Observa-se no mesmo Documento que o Poder Marítimo resulta da capacidade de integrar os recursos de que dispõe a Nação para utilização do mar e das águas interiores, seja como instrumento de ação política e militar, seja como fator de desenvolvimento econômico e social. Por seu turno, o Poder Nacional é a capacidade do conjunto dos homens e dos meios constituintes da Nação para alcançar e manter os objetivos nacionais. Estes "representam a cristalização das necessidades, interesses e aspirações que, em determinada fase de sua evolução histórica e cultural, a Nação busca alcançar" (BRASIL, 2014, p. 11). Deve-se lembrar que, no concernente ao conceito de poder na ciência Relações Internacionais, há discordância entre os estudiosos sobre 0 que ele é; como opera; como medi-lo. Sendo assim, seguindo o exemplo de Erik Gartzke, adota-se a ideia geral do poder como habilidade para fazer algo, para agir (GARTZKE, 2010). De modo mais específico, para Mario Stoppino, "a palavra Poder designa a capacidade ou a possibilidade de agir, de produzir efeitos" (BOBBIO, 1998, p. 933). Essa discussão privilegia a capacidade militar brasileira de agir, e o efeito a ser produzido no que se refere à capacidade de defender a Amazônia Azul.

Como referido acima, o Poder Naval é aqui entendido como parte integrante do Poder Marítimo, e este, como instrumento de ação militar. Assim, argumenta-se, no presente artigo, ser uma necessidade premente conjugar, no âmbito da política externa brasileira, o poder político, na acepção da defesa do Direito Internacional, ao poder militar, na perspectiva do fortalecimento do Poder Naval. Defende-se aqui a ideia de que poder militar e Direito Internacional devem estar conjugados na realidade interna e na ação internacional no Brasil do século XXI. A observância ao Direito Internacional é característica da identidade do País e assim deve permanecer. No entanto, para se buscar garantir os interesses deste num ambiente internacional anárquico, em que a emergência de conflitos não pode ser descartada, há que se dispor igualmente do poder militar que respalde os objetivos nacionais brasileiros. Há que se considerar que a costa brasileira tem aproximadamente 7,4 mil quilômetros de extensão e o Brasil tem, 
sob sua jurisdição, 3,5 milhões de quilômetros quadrados $\left(3.574 .811 \mathrm{~km}^{2}\right)$ de espaço marítimo correspondentes à Zona Econômica Exclusiva (ZEE). Apenas o Brasil pode explorar economicamente esse espaço e suas riquezas (MARINHA DO BRASIL, 2019). Assim, imprescindível é que se disponha de poder naval adequado para proteger a referida área.

Em 2004, o Brasil submeteu à Comissão de Limites da Plataforma Continental (CLPC), organismo internacional estabelecido pela Convenção das Nações Unidas sobre o Direito do Mar (CNUDM) de 1982, pedido de extensão dos limites de sua plataforma continental, além das 200 milhas náuticas ( $370 \mathrm{~km}$ ) (UNITED NATIONS, 2004). O pleito brasileiro correspondente a uma área de mais de 2,1 milhões de quilômetros quadrados $\left(2.094 .701 \mathrm{~km}^{2}\right)$ de extensão de limites de plataforma continental, o que elevaria as dimensões do espaço marítimo brasileiro para 5,7 milhões de quilômetros quadrados $\left(\mathrm{km}^{2}\right)$. Atualmente, o país aguarda as recomendações da Comissão para que esses limites sejam fixados internacionalmente (MARINHA DO BRASIL, 2019).

A Marinha do Brasil e o Governo do País convencionaram denominá-la Amazônia Azul, já que corresponde a uma área maior que a Amazônia Verde. A Amazônia Azul se encontra distribuída nas regiões Norte e Sudeste/Sul do território nacional. Nesse sentido, além do significativo potencial econômico desse espaço, a referida Força o entende como a última fronteira do País. Deste modo, entre as vertentes de estudo propostas pela instituição, figura a Soberania. A Marinha defende que, diante da complexidade da tarefa de proteger a Amazônia Azul, faz-se necessário o adequado aparelhamento desta Força Militar.

É sob essa perspectiva, da necessidade de se aparelhar esta Força, que cabe aqui a discussão sobre os aspectos relativos à importância do Poder Naval para que o Brasil exerça uma presença internacional mais proeminente nesse cenário pós-Guerra Fria. Este período se caracteriza pela existência de uma unipolaridade militar. De igual modo, no campo político, numa alusão ao pensamento de Gelson Fonseca Júnior, o referido período se caracteriza por estar em transformação no que concerne a ordem internacional, o que abre brechas para que potências médias como o Brasil, ocupem lugar de maior proeminência e destaque (FONSECA Jr., 1998).

Quanto aos aspectos metodológicos, opta-se pelo método qualitativo, no nível exploratório. As técnicas de pesquisa utilizadas foram bibliográfica e documental. Observa-se que o tema em estudo corresponde a um fenômeno de múltiplas dimensões e de caráter complexo, relevante e que está em andamento (GIL, 1999; CERVO; BERVIAN, 2002; MARCONI; LAKATOS, 2010). 
O presente artigo está dividido em três partes. A primeira parte trata da Amazônia Azul, sua importância econômica, política e estratégica para o país, além das questões relacionadas à soberania nacional. Nela, apresenta-se a oceanopolítica, nosso conceito central. Na segunda, trata-se da relação entre o Direito Internacional do uso dos mares e a postura do Estado brasileiro. Nessa parte, faz-se uma breve retrospectiva histórica até os dias atuais. Na terceira e última parte, que antecede a conclusão, discutem-se aspectos do PROSUB, sob a perspectiva da importância do poder naval brasileiro para a Defesa do Brasil, no geral, e da defesa da Amazônia Azul, em particular.

\section{AMAZÔNIA AZUL: UM CONCEITO, UMA REALIDADE EM CONSTRUÇÃO}

A denominação Amazônia Azul aponta para a importância da riqueza das águas, do solo e subsolo marinhos, e a plataforma continental estendida que compõem o oceano do Brasil. Para llques Barbosa Júnior, hoje Comandante da Marinha do Brasil, a Amazônia Azul é um conceito político-estratégico, o qual envolve o Mar Territorial, a Zona Contígua, a Zona Econômica Exclusiva e a Plataforma Continental. No mesmo diapasão, sintetizam Alcindo Gonçalves e Maria Luiza Machado Granziera (2012), que a Amazônia Azul é uma área formada pela soma da Zona Econômica Exclusiva e da Plataforma Continental. Já conforme definição do VIII Plano Setorial para os Recursos do Mar, a Amazônia Azul é:

área marítima sob jurisdição nacional de dimensões que correspondem a, aproximadamente, metade do território nacional, ou ainda, pela semelhança de recursos naturais, comparada à outra Amazônia, assim chamada pela Marinha com o intuito de destacar para a sociedade a importância estratégica e econômica do mar que nos pertence (CIRM,VIII PSRM, 2012, p. 34).

A delimitação da área em tela, bem como a garantia do exercício da soberania sobre ela, para além de configurarem uma questão de política externa brasileira são, mais que uma política de governo, uma política de Estado. Assim, ações do Estado brasileiro balizaram até o presente momento todo o processo de estudos, bem como o próprio pleito junto à ONU para a configuração da Amazônia Azul. Essas ações precisam ter continuidade para, findo o processo de reconhecimento internacional a partir da CNUDM, haja a proteção da área e a plena possibilidade de explotar e explorar, inclusive e fundamentalmente, com a presença do Poder Naval do Brasil. Por esta razão, o conceito de 
oceanopolítica mostra-se instrumento apropriado para a análise e a discussão de questões relativas à Amazônia Azul.

A Oceanopolítica é nossa opção conceitual porquanto seu propósito central é fazer com que a gestão política aprecie a influência do mar no ciclo vital do Estado. Importa-nos a perspectiva da relação com o Estado, o poder e as relações políticas. Para o ideólogo do conceito de Oceanopolítica, o Almirante chileno Jorge Martínez Busch, devido à origem europeia, a geopolítica está relacionada a uma realidade válida para o Hemisfério Norte e caracteriza um problema que tem como ponto central as terras (BUSCH, 1993). Já o espaço geográfico do Hemisfério Sul revela situação particular vinculada aos espaços oceânicos. Ao Sul do Equador terrestre, predominam as águas dos Oceanos Pacífico, Atlântico e Índico, espaço que Busch denomina Oceânico Hemisférico Austral. Por ser permanente a influência dos oceanos nos Estados do Hemisfério Austral, o mar deve estar sempre presente na mente de seus governantes. Estes, ao formularem suas políticas, devem considerar a presença dos oceanos e sua influência no entorno geográfico dos respectivos países (BUSCH, 1993).

Assim, conforme denomina Busch (1993), a Oceanopolítica é a consideração da existência do oceano no entorno geográfico e a influência desta sobre as decisões políticas. No entender do almirante, a Oceanopolítica deve permitir que os governantes busquem o bem comum a partir da consideração de que o mar e os espaços oceânicos configuram espaço de desenvolvimento e crescimento do Estado. Oceanopolítica não é sinônimo de política marítima ou de política oceânica, a qual lida com problemas de desenvolvimento do espaço terrestre por meio do espaço marítimo e tem como foco aspectos relativos ao desenvolvimento dos espaços marítimos. Em sua especificidade, a Oceanopolítica conduz à ocupação do espaço oceânico na condição de verdadeiro espaço de desenvolvimento e crescimento do Estado, concepção esta que vai além da consciência marítima. Em defesa do estabelecimento de um processo intelectual que construa esse pensamento, Busch assevera ser a Oceanopolítica, própria do Hemisfério Austral, em resposta à geopolítica clássica (BUSCH, 1993).

Para llques Barbosa Júnior, tanto a Geopolítica quanto a Oceanopolítica orientam o Estado para o emprego do Poder Nacional. No entanto,

a Oceanopolítica desenvolve uma série de conceitos decorrentes de ordenamento jurídico próprio, de prioritários estudos voltados para o emprego de sistemas hidroviários e portuários, sejam fluviais ou marítimos, dos recursos naturais existentes no mar, da mentalidade marítima e das conexões comerciais, históricas e culturais com países. Tais conexões, em muitas oportunidades, estão separadas por espaços oceânicos sem limitações e interconectadas (BARBOSA Jr., 2009, p. 61). 
Para 0 autor, as fronteiras da atualidade devem ser estabelecidas pela forma que o Estado emprega o Poder Nacional nos espaços oceânicos. Ele considera o Estado como núcleo de irradiação de poder nacional e, a partir daí, aponta que "os conceitos da Oceanopolítica demonstram que as fronteiras são delineadas nos espaços oceanopolíticos, onde são projetadas as influências dos Estados" (BARBOSA Jr., 2009, p. 64).

No entender de Barbosa Júnior, é a partir dos conceitos da Oceanopolítica, e não da Geopolítica, que deve ocorrer o entendimento da importância da ocupação dos espaços oceânicos, o que destaca a crescente relevância da CNUDM. A partir dela, um novo ordenamento jurídico pode estar contribuindo para que se estabeleça um novo tipo de fronteiras, as marítimas. Dessa forma, ele preliminarmente conceitua:

Oceanopolítica envolve o Estado como elemento central para a adoção de decisões soberanas, considerando os espaços oceânicos, sobre o destino de sua população, assim como nas relações de poder com outros estados e, considerando a conjuntura político-estratégica internacional, com os demais atores das relações internacionais (BARBOSA Jr., 2009, 62).

Por seu turno, Tereza Cristina Nascimento França define o conceito de oceanopolítica como "o estudo das relações entre os Estados e os espaços marítimos" (FRANÇA, 2012, p. 63). A autora aponta que o mar foi sempre considerado veículo de projeção de poder, sendo o período dos descobrimentos, protagonizados por Espanha e Portugal, que buscavam estabelecer seus domínios territoriais, exemplo dessa realidade. Nesse sentido, destaca que o Tratado de Tordesilhas foi uma tentativa portuguesa de reassegurar uma repartição mais adequada aos seus interesses. Ademais, lembra a autora que a mobilidade marítima, especialmente entre os séculos XVIII e XIX, significou o desenvolvimento processual de uma consciência do mar como um espaço que permitia a abertura de novas possibilidades de valor econômico e militar.

Rodrigo Fernandes More enfatiza o potencial da oceanopolítica em promover uma leitura dos temas oceânicos com foco "na construção nas relações de poder entre estados, objeto da oceanopolítica", segundo suas palavras (MORE, 2013, p. 233). A relação entre poder e direito é o cerne de nossa discussão. Lembra More que a perspectiva dos Estados sobre a importância dos espaços marítimos na construção de relações de poder e de direito tem sofrido mudança a partir da regulação jurídica e do aumento da compreensão do significado das riquezas dos espaços globais comuns. More (2013) assevera ser importante que o Brasil defina políticas e ações que afirmem 
a soberania sobre o próprio espaço oceânico, o que se aplica naturalmente à proteção da Amazônia Azul.

Para tratar do tema Amazônia Azul torna-se necessário compreender a importância do entendimento do limite da plataforma continental além das duzentas milhas e a responsabilidade no sentido de inibir interpretações equivocadas quanto à aplicação dos critérios estabelecidos pelo artigo 76 da Convenção de Montego Bay, de 1982. Para tanto, a CNUDM estabeleceu a Comissão de Limites da Plataforma Continental (CLPC) e determinou que os Estados costeiros devem submeter "informações sobre os limites da plataforma continental, além das 200 milhas marítimas das linhas de base, a partir das quais se mede a largura do mar territorial" à CLPC.

A referida Comissão é instituição internacional e órgão técnico e científico, e não órgão político ou jurídico (SILVA, 2015). Cabe a ela manter atenção para a coerência das propostas feitas pelos Estados costeiros em suas submissões, para evitar situações onde haja interferência na autonomia dos Estados costeiros em estabelecer seus limites exteriores. Nesse sentido, cumpre-nos apresentar uma definição de plataforma continental, que para Machado (2015), corresponde ao prolongamento direto do continente sob o mar, onde os continentes parecem repousar e cujas características geológicas são semelhantes às da massa continental.

O conceito jurídico de plataforma continental, conforme definido pelo Direito Internacional, é recente e ultrapassa os limites da plataforma continental geomorfológica. Ele engloba também os demais componentes da margem continental, ou seja, o talude e a elevação continental. De acordo com a $\mathrm{CNUDM}^{4}$, a plataforma continental de um Estado costeiro compreende o leito e o subsolo das áreas submarinas que se estendem além do seu mar territorial, em toda a extensão do prolongamento natural do seu território terrestre, até ao bordo exterior da margem continental ou até uma distância de 200 milhas náuticas ${ }^{5}$. Na Plataforma Continental ${ }^{6}$, o Estado costeiro exerce direitos de soberania para fins de exploração e aprofundamento dos seus recursos naturais e esses direitos são exclusivos, ou seja:

$\S 2^{\circ}$. Os direitos a que se refere o parágrafo $1^{\circ}$ são exclusivos no sentido de que, se o Estado costeiro não explora a plataforma continental ou não aproveita os recursos naturais da mesma, ninguém pode empreender estas atividades sem o expresso consentimento desse Estado.

\footnotetext{
${ }^{4}$ Cf.: artigo 76, parágrafo 1

${ }^{5}$ Destaca-se que esta é uma definição jurídica e não deve ser confundida com a definição científica.

${ }^{6}$ Cf.: artigo 77
} 
§3‥ Os direitos do Estado costeiro sobre a plataforma continental são independentes da sua ocupação, real ou fictícia, ou de qualquer declaração expressa (CNUDM, 1982).

Para Trindade (2014, p. 212) a doutrina da Plataforma Continental, assim como já ocorre com o regime das águas territoriais, revela claramente a tendência de expansão da jurisdição dos Estados costeiros. Do mesmo modo, os trabalhos da III Conferência da ONU sobre o Direito do Mar "apontam no sentido do reconhecimento da zona econômica exclusiva até as 200 milhas, admitindo ainda a possibilidade de, para os Estados de longa plataforma continental estendê-la - segundo determinados critérios - até o limite externo de 350 milhas".

Um novo conceito se viera juntar às velhas noções de direito do mar: o da plataforma continental. Esboçado vagamente desde os primeiros decénios do século, o conceito de plataforma se afirma a partir da pioneira proclamação do Presidente dos Estados Unidos, em 1945, e os Estados, um após outro, afirmam seu direito à continuação geológica de seu território que se estende sob as águas marinhas. A plataforma é, sobretudo, fonte de riquezas minerais, em seu solo e $\mathrm{cm}$ seu subsolo. Mas descobre-se que ela tem íntimas relações com os recursos vivos das águas superjacentes (RODRIGUEZ, 1970, p. 125).

A CNUDM estabelece o regime jurídico da plataforma continental, onde define o conceito, determina os direitos do Estado costeiro, assim como os direitos e liberdades de outros Estados, em dez artigos. A Convenção, como já exposto, estabelece um conceito jurídico de plataforma continental, de modo que nenhum outro Estado pode explorar a plataforma sem a autorização do Estado costeiro, e os direitos deste são independentes de sua ocupação, real ou fictícia, ou de qualquer declaração expressa. O Estado costeiro exerce direitos soberanos sobre a sua plataforma continental, e naturalmente sobre os seus respectivos recursos.

No que concerne ao Brasil, em 12 de setembro de 1974 foi criada a Comissão Interministerial para os Recursos do Mar (CIRM), pelo Decreto no $74.557^{7}$, com a finalidade de coordenar e implementar a política marítima no Brasil através da Política Nacional para os Recursos do Mar (PNRM), instituída em 1980. A CIRM também tem como finalidade orientar o desenvolvimento das atividades que visem à efetiva utilização e promova a integração ao espaço brasileiro e a exploração e aproveitamento dos recursos vivos, minerais e

\footnotetext{
${ }^{7}$ Revogado pelo Decreto $\mathrm{n}^{\circ} 3.939$, de 26 de setembro de 2001, alterado pelos Decretos nos: 4.815, de 20 de agosto de 2003; 6.107, de 2 de maio de 2007; 6.484, de 17 de junho de 2008; 6.756, de 2 de fevereiro de 2009 e 6.979, de 8 de outubro de 2009 (MB, CERIM, 2017)
} 
energéticos do Mar Territorial, da Zona Econômica Exclusiva e da Plataforma Continental, de acordo com os interesses nacionais, de forma racional e sustentável para o desenvolvimento socioeconômico do País (PNRM, 2005).

Após o reconhecimento da importância do mar para o desenvolvimento do Brasil, foram divulgadas as Diretrizes Gerais da Política Nacional para os Recursos do Mar (PNRM), traçadas em 1980 pela Comissão Interministerial para os Recursos do Mar, contendo as linhas básicas que deverão nortear todos os esforços nas áreas de ensino, pesquisa, exploração e explotação dos recursos do mar.

Assim como a finalidade, os objetivos da PNRM encontram-se direcionados para a segurança nacional e para 0 desenvolvimento de tecnologias necessárias às atividades marítimas. $O$ mesmo ocorre no que se refere aos materiais e equipamentos. Para isso é preciso o apoio da iniciativa privada e a colaboração interna, também em busca de cooperação estrangeira para o desenvolvimento de ações conjuntas (FONSECA Jr., 1998).

Em 2004, a partir da abertura do processo de submissão brasileira para a ampliação do espaço oceânico, tornou-se necessário o investimento em ensino e pesquisa, para a obtenção de mão de obra especializada, assim como de tecnologia de ponta para o planejamento e gerenciamento das atividades.

Para Morris (1979), o direcionamento dado a construção da política oceânica brasileira, na década de 1970, já podia ser considerado um exemplo positivo para muitos países e destacou que o crescimento do poderio naval e da marinha mercante, a exploração mais intensiva dos recursos oceânicos e um mar territorial de 200 milhas desde 1970 teve um impacto crescente no desenvolvimento nacional. Para o autor a política oceânica representava um novo momento do desenvolvimento brasileiro e que desde o início da década de 1970 já havia uma quantidade relevante de registros históricos, apresentando iniciativas relativas à elaboração de políticas internas para o mar. Acrescentou ainda que a responsabilidade da Marinha pelo desenvolvimento e segurança da extensa rede fluvial do país vinculou os assuntos marítimos à integração nacional.

Curiosamente, segundo Vidigal et al (2006), em 1508 já existiam valiosas informações sobre a costa do país e em 1934 as preocupações nacionais com a pesca, a oceanografia e a meteorologia marinha, deram origem ao Instituto Oceanográfico Brasileiro ${ }^{8}$.

\footnotetext{
${ }^{8}$ Em 1946 foi criado o Instituto Paulista de Oceanografia, a primeira instituição não-governamental de pesquisa oceanográfica e em 1951 foi incorporado à Universidade de São Paulo, recebendo o nome de Instituto Oceanográfico.
} 
Cabe observar que a criação da CIRM, em 1974, foi um exemplo do compromisso do Governo brasileiro no que se refere ao mar, o que representou um grande impulso para a evolução da oceanografia no Brasil. Observa-se ainda que o Brasil apresenta, invariavelmente, preocupação com a defesa de seu litoral, assim como, com a proteção dos seus recursos naturais submersos e todas as demais riquezas advindas do mar. Para Morris (1979), os assuntos do oceano ocupam uma posição importante na política internacional e na política externa por causa das mudanças tecnológicas, econômicas e políticas. Novas possibilidades de extração de recursos e maior uso dos oceanos demandam respostas nacionais e internacionais complexas. Sendo assim, pode-se dizer que o Brasil, através do seu posicionamento firme nas reuniões internacionais, em defesa de seu espaço marítimo, se consolidou como potência costeira a partir do momento em que conduziu sua política marítima de acordo com o sistema internacional.

Morris (1979) destacou que os aspectos internacionais relativos aos assuntos oceânicos brasileiros são da competência da política externa brasileira, de modo que a política oceânica brasileira reflete as três implicações da política externa: econômica, política e segurança. $O$ autor ainda acrescentou $O$ pragmatismo. A aplicabilidade das quatro características da política externa à política marítima brasileira pode ser observada explicitamente. Para o autor, esse processo foi muito importante para o Brasil, na qualidade de grande potência emergente e destacou que o posicionamento estratégico do Estado brasileiro no Atlântico Sul apresentou subsídios que contribuíram para o entendimento e a análise da evolução da política oceânica.

Em 1986, o Governo brasileiro ${ }^{9}$, no âmbito da Comissão Interministerial para os Recursos do Mar (CIRM), deu início ao projeto para efetuar o levantamento dos limites externos de sua plataforma continental ${ }^{10}$ além das 200 milhas marítimas, com base nos dispositivos do artigo 76 da CNUDM. O trabalho teve início em junho de 1987 e se estendeu até novembro de 1996. Como consequência, a CIRM elaborou o Plano de Levantamento da Plataforma Continental Brasileira (LEPLAC), sob a coordenação da Marinha do Brasil.

Morris (1979) destaca que a política oceânica representava uma nova face do desenvolvimento brasileiro, que desde o início da década de 1970 já contava com um considerável registro histórico de iniciativas voltadas à formulação de políticas internas para o mar. Para Morris este fato adquiriu

\footnotetext{
${ }^{9}$ Mesmo antes da adoção da Lei no ${ }^{8} .617 / 1993$, que dispõe sobre o mar territorial, a zona contígua, a zona econômica exclusiva e a plataforma continental brasileiros.

${ }^{10}$ Em junho de 1987, o navio oceanográfico Almirante Câmara, da DHN, realizou a primeira comissão de levantamento da plataforma continental brasileira.
} 
considerável importância no caso de uma grande potência emergente como 0 Brasil. A posição estratégica do Estado brasileiro no Atlântico Sul proporciona excelentes condições para a análise evolutiva da política para o mar. Sob esta ótica, na III CNUDM, o Brasil interferiu e sofreu interferências significativas no curso das negociações. A participação do país neste evento foi particularmente importante para a organização de uma política internacional para o mar.

Há que se destacar que ao final da Conferência, o estabelecimento de um regime global para os oceanos permitiu ao Estado brasileiro formular regras específicas, em conformidade com a CNUDM, para regulamentar os principais setores marítimos brasileiros. Desse modo, o Brasil, que tem uma área oceânica aproximada de $3.539 .919 \mathrm{~km}^{2}$, pleiteou, junto à Comissão de Limites da Plataforma Continental (CLPC) da Convenção das Nações Unidas sobre o Direito do Mar (CNUDM), a extensão dos limites de sua Plataforma Continental, além das 200 milhas náuticas (370 km), correspondente a uma área de 963 mil $\mathrm{km}^{2}$ (SECIRM, 2019).

De igual modo, cabe lembrar que o Brasil é signatário da Convenção das Nações Unidas sobre o Direito do Mar (CNUDM), promulgada pelo Decreto 1530/95. Em 4 de janeiro de 1993, foi sancionada a Lei n. 8.617/93, enquadrando a normativa interna brasileira e os limites marítimos brasileiros aos preceitos preconizados pela CNUDM, inclusive com a revogação de normas que the fossem contrárias.

Abria-se a possibilidade de que o Brasil aproveitasse a oportunidade criada pelo LEPLAC para não somente levantar os dados necessários ao procedimento na Comissão sobre o bordo exterior de sua margem continental, como também aumentar seus conhecimentos sobre o meio ambiente marinho e sobre os fundos marinhos internacionais adjacentes a sua plataforma estendida. O trabalho de campo inicial do LEPLAC se estendeu por cerca de dez anos, de modo a abranger os cerca de 8 mil km da costa brasileira, e produziu cerca de 150 mil quilômetros de perfis submarinos de todo o litoral (MACHADO, 2015).

Encerrada a etapa de coleta de dados, iniciou-se o trabalho igualmente complexo de análise e interpretação das informações obtidas e de preparação da proposta a ser apresentada à CLPC. A essa altura, a CNUDM tinha entrado em vigor e o Brasil já poderia, caso em condições de fazê-lo, apresentar uma proposta de limite exterior de sua plataforma continental além das 200 milhas marítimas à CLPC, que começou a funcionar em 1997 (SILVA, 2011). Os dezoito anos de atividades dessa primeira fase do LEPLAC permitiram ao Brasil tornarse o segundo Estado no mundo e o primeiro em desenvolvimento a apresentar proposta para exame à CLPC. 
Para Figueirôa (2014), o Brasil, que havia sido, até então, pioneiro no trabalho de levantamento dos limites exteriores de sua plataforma continental e em fase avançada de formulação de sua proposta, estava preparado para submeter à CLPC no prazo originalmente fixado na CNUDM e destaca que:

o Plano ressaltava a importância particular de que se reveste o levantamento da plataforma continental brasileira para 0 aumento da presença brasileira no Atlântico Sul, por meio de uma atividade pioneira que poderia estimular outros Estados costeiros e servir como base de cooperação com outros países da região que a buscassem. Sublinhava sua utilidade para cumprir um objetivo essencial da política exterior do Brasil em relação ao Atlântico Sul (FIGUEIRÔA, 2014, p. 192).

Em 17 de maio de 2004, o Brasil submeteu formalmente as informações sobre os limites exteriores de sua plataforma continental além das 200 milhas marítimas à CLPC, tornando-se o segundo Estado costeiro ${ }^{11}$ a fazer a solicitação e o primeiro país em desenvolvimento a fazê-lo. As informações brasileiras procuraram atender a todos os requisitos formais estabelecidos pela UNCLOS e pelas Regras de Procedimento e Diretrizes Técnicas e Científicas da Comissão ${ }^{12}$.

Cumpre destacar a importância do levantamento da plataforma continental brasileira para a política exterior do Brasil em relação ao Atlântico Sul, pois, além dos aspectos políticos, econômicos, científicos, estratégicos e ambientais, apresentados por Figueiroa (2014), esse conjunto de atividades acentua a presença pioneira do Brasil no Atlântico Sul.

Desse modo, vale lembrar a importância do planejamento de atividades ligadas ao interesse nacional e à execução das políticas públicas definidas para o território marítimo, bem como à efetiva implementação de atividades ligadas ao melhor aproveitamento das riquezas e potencialidades contidas nesta extensa área. O Estado brasileiro não pode prescindir de atuar nessa região. Destaca-se também a importância de se destinarem os meios necessários para proporcionar uma adequada vigilância e proteção dos interesses do Brasil no mar e do plano exercício da soberania nacional (MARINHA DO BRASIL LEPLAC; SECIRM, 2019).

Em conformidade com o artigo 76, parágrafo 8, da CNUDM ○ Brasil encaminhou à CLPC em 10 de abril de 2015, novas informações sobre a proposta de extensão de limites da plataforma continental da Região Sul do Brasil (fase II da LEPLAC), que extrapolam as 200 milhas marítimas tradicionais.

\footnotetext{
${ }^{11}$ Em 20 de dezembro de 2001, a Rússia foi o primeiro Estado costeiro a submeter um pedido de extensão de limites de sua PC à CLPC. Ver solicitação em CLCS/32 e resposta em CLCS/34 de 27 de junho de 2002. ${ }^{12}$ Ver em CLCS/42 e as recomendações em CLCS/54 de 04 de abril de 2007.
} 
A apresentação da submissão parcial revisada à Comissão foi feita em 25 de agosto de 2015, onde o chefe da delegação brasileira e representante permanente adjunto do Brasil junto à ONU, Carlos Sérgio Sobral Duarte observou ainda que, a área da plataforma continental abrangida pela apresentação não estava sujeita a quaisquer litígios.

Entre outubro a dezembro de 2017, foram apresentadas as considerações da submissão parcial revisada feita pelo Brasil em respeito à Região Sul do Brasil. No que se refere à Margem Equatorial brasileira, foi feita em 8 de fevereiro de 2018. Cabe destacar o papel do Almirante Jair Alberto Ribas Marques, um dos três Vice-Presidentes da CLPC, por prestar assessoria técnica e científica à delegação brasileira e informar que a área da plataforma continental coberta pela submissão, do mesmo modo que a Região Sul, não estava sujeita a nenhuma disputa.
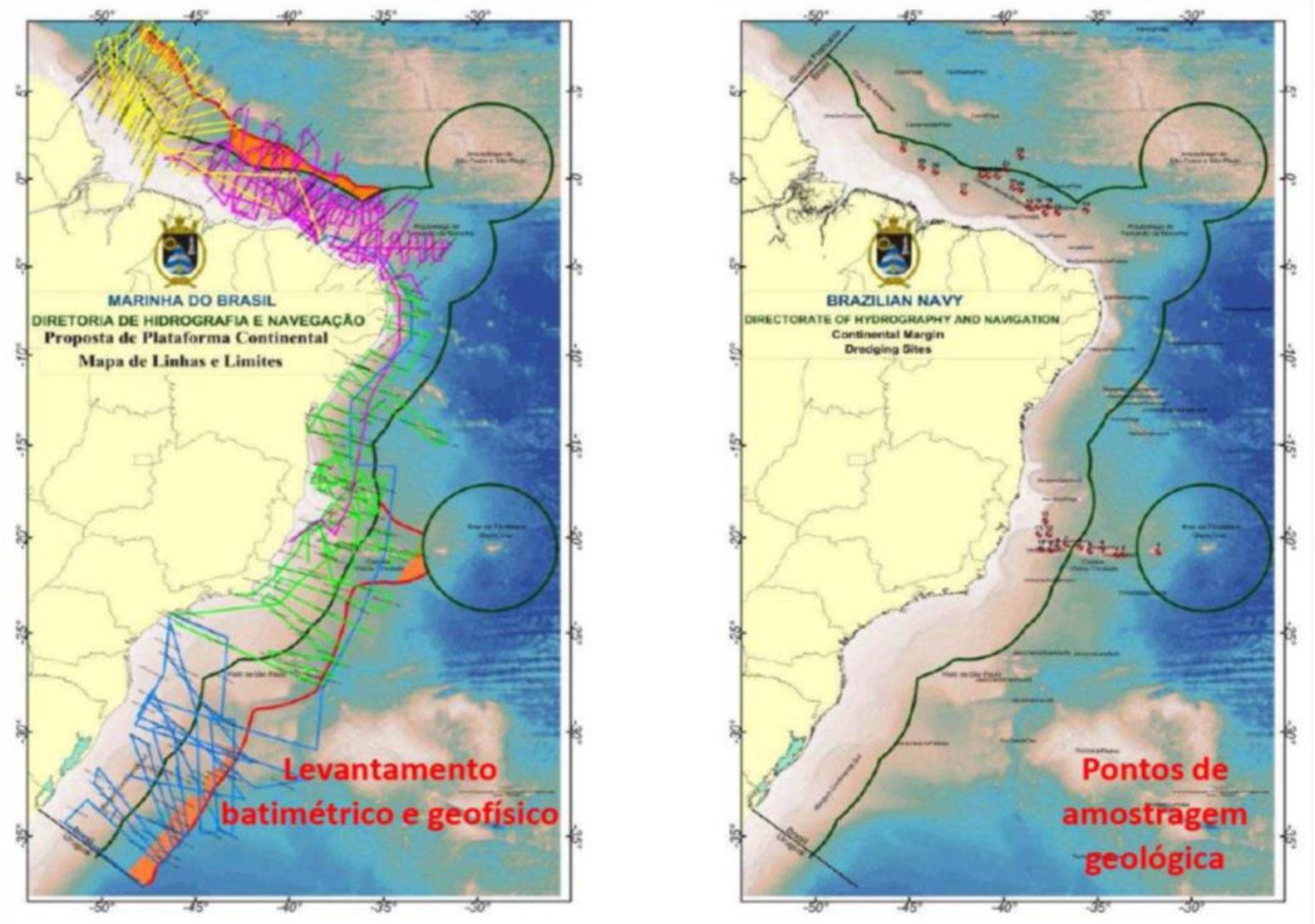

Figura 1: LEPLAC (Fase II).

Fonte: DHN (2017)

Recentemente, em 7 de dezembro de 2018, o Brasil submeteu à CLPC, também em conformidade com 0 artigo 76, parágrafo 8, da Convenção, informações sobre os limites da plataforma continental além das 200 milhas náuticas, em relação à Margem Oriental e Meridional Brasileira. Cabe observar que para a elaboração da proposta revisada (Fase II da LEPLAC), a margem 
continental brasileira foi dividida em três áreas distintas: Margem Sul, Margem Equatorial e Margem Oriental e Meridional. A proposta da Região Sul, inserida em parte da Margem Meridional, foi encaminhada à ONU em abril de 2015 (CLCS/90) e apresentada à CLPC em agosto do mesmo ano. Em março de 2019, a CLPC aprovou na sua totalidade o Limite Exterior proposto pelo Brasil relativo à essa Submissão, incorporando à Plataforma Continental uma área de cerca de $170.000 \mathrm{~km}^{2}$. A consideração a respeito desta submissão parcial revisada foi incluída na agenda provisória da $50^{\underline{a}}$ sessão da Comissão, realizada de $1^{\circ}$ de julho a 16 de agosto de 2019, ainda sem resposta.

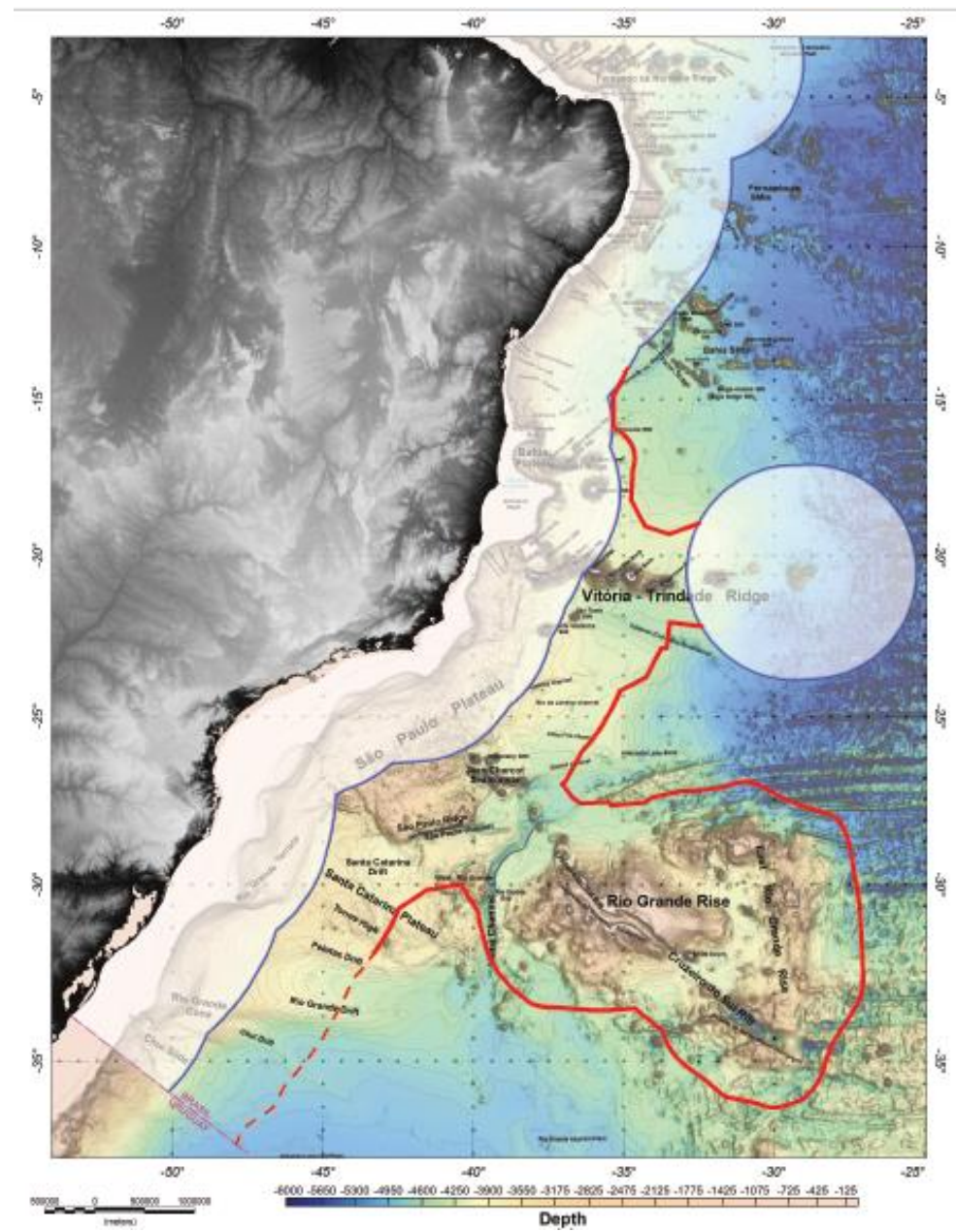

Figura 2: Delimitação da Submissão parcial brasileira à CLPC para as margens Oriental e Meridional - 2018. Fonte: CLCS - Executive Summary (2018).

A nova submissão representa a continuidade dos esforços realizados para que se alcance a totalidade do pleito de extensão de limites da plataforma continental brasileira além das 200 milhas. A proposta da Margem Equatorial foi apresentada na Reunião Plenária da Comissão de Limites em março de 2018 e a proposta da margem Oriental e Meridional, com a inclusão da Elevação de Rio 
Universidade Federal Fluminense

Instituto de Estudos Estratégicos

Grande (ERG - $920.000 \mathrm{~km}^{2}$ ), foi encaminhada à ONU em dezembro de 2018 (CLCS103/108), com previsão para análise a partir de 2023.

Em reconhecimento a grande importância da ERG para o Brasil, foram criados programas para aumentar sua presença no Atlântico Sul. Dentre os programas encontram-se: o Programa de Prospecção e Exploração de Recursos Minerais da Área Internacional do Atlântico Sul e Equatorial (PROAREA), coordenado pela Comissão Interministerial para os Recursos do Mar (CIRM). Esta, por sua vez, possui um projeto específico para avaliar a Potencialidade Mineral da Elevação do Rio Grande (PROERG), com o objetivo de estudar as crostas cobaltíferas na região.

Em novembro de 2015, o Brasil assinou com a Autoridade Internacional dos Fundos Marinhos (ISBA), órgão ligado à ONU, um contrato para a exploração de crostas cobaltíferas na ERG, com exclusividade, por quinze anos. Também concedeu ao Brasil o direito de pesquisar o potencial mineral, além de outras pesquisas científicas nos campos da Biologia, Geologia, Geofísica, dentre outras da região ${ }^{13}$.

Com a inclusão da ERG nessa submissão, a Amazônia Azul poderá alcançar uma área oceânica de cerca de 5,7 milhões de $\mathrm{km}^{2}$ sob jurisdição brasileira (CLCS, 2018; SECIRM, 2019). Cabe sublinhar que o levantamento da plataforma continental também tem importância para a política exterior do Brasil em relação à posição brasileira no Atlântico Sul. De acordo com More e Barbosa Júnior (2012) as dimensões da Amazônia Azul e a continuidade do espaço oceânico permitem que suas vertentes sejam analisadas sob a perspectiva do Atlântico Sul.

Sendo assim, passa a ser primordial que o Estado brasileiro desenvolva a capacidade de monitorar essa vasta extensão, o que inclui o planejamento das atividades relacionadas ao interesse nacional e à execução de políticas públicas definidas para o território marítimo. Há que se implementar atividades que permitam explorar as riquezas e as potencialidades da Amazônia Azul, bem como alocar recursos necessários para uma adequada vigilância e proteção dos interesses do Brasil no mar. Nesse sentido, é fundamental o fortalecimento do Poder Naval brasileiro, de forma a promover a efetiva proteção desses

${ }^{13}$ A ERG corresponde a uma cordilheira montanhosa submersa, que se eleva de mais de três mil metros do fundo oceânico. 
interesses, consoante à realidade das novas fronteiras nacionais que se constroem no âmbito da CNUDM.

\section{O DIREITO INTERNACIONAL DO USO DOS MARES E O BRASIL}

A dificuldade para a codificação do Direito do Mar pode ser observada historicamente, por conta da instabilidade causada pela carência de regras do Direito Internacional. A lacuna começou a ser fechada em dois momentos: as Conferências da Paz de Haia (1889-1907) e a criação da Liga das Nações (1919). A criação da Liga das Nações incentivou as discussões sobre a necessidade de se estabelecer regras capazes de disciplinar o uso comum do mar. Em 1921, a Conferência de Barcelona criou "a convenção e o estatuto sobre a liberdade de trânsito e sobre o regime das águas navegáveis de interesse nacional" (MENEZES, 2015, p. 28).

Em 1930, a Liga das Nações convocou uma Conferência para criar um protocolo único capaz de fixar a um entendimento comum sobre o uso do mar e a delimitar o mar territorial e zona contígua. Em 1958 e em 1960, já sob o amparo da Organização das Nações Unidas (ONU), ocorreram as duas primeiras conferências sobre o Direito do Mar, ambas realizadas em Genebra, na Suíça. Essas conferências, no entanto, não lograram êxito. Em 1958, passados mais de dez anos da constituição da ONU, foi possível "acertar algum consenso entre nações e se consolidar a primeira Conferência sobre o Direito do Mar". Conceitos como o de mar territorial, zona contígua, alto-mar, entre outros surgiram, mesmo que em contraposição ao desejo de plena liberdade dos mares de alguns atores internacionais. Simultaneamente, procurava-se garantir condições mínimas de proteção aos Estados costeiros (BEIRÃO, 2014, p. 130).

Nesse contexto, insere-se a Convenção das Nações Unidas sobre o Direito do Mar. Ela corporifica um tratado institucional, sob a égide da Organização das Nações Unidas, como tentativa de governança global para a reorganização dos espaços oceânicos. Atualmente o princípio da liberdade do alto-mar encontra-se consolidado na CNUDM, documento que codificou costumes marítimos seculares. Ele inovou ao criar novos princípios e normas compatíveis com os avanços científicos e tecnológicos da contemporaneidade.

A CNUDM é um tratado multilateral celebrado sob as recomendações ONU, que define e codifica conceitos herdados do direito internacional referentes aos assuntos marítimos, como mar territorial (MT), zona econômica exclusiva (ZEE), plataforma continental (PC) e outros, e estabelece os princípios gerais da exploração dos recursos naturais do mar, como os recursos vivos, os do solo e 
os do subsolo. A Convenção também criou o Tribunal Internacional do Direito do Mar, competente para julgar as controvérsias relativas à interpretação e à aplicação daquele tratado.

A Convenção buscou, dentre outros, estabelecer, preservando a soberania de todos os Estados, uma ordem jurídica para os mares e oceanos que facilitasse as comunicações internacionais que promovesse o uso pacífico dos mares e oceanos, a utilização equitativa e eficiente dos seus recursos, a conservação dos recursos vivos e o estudo, a proteção e a preservação do meio marinho (CNUDM, 1982).

Em 1968, o Governo brasileiro fixou limite para sua plataforma através do Decreto $n^{\circ}$ 62.837, que dispôs sobre exploração e pesquisa na plataforma submarina do Brasil, nas águas do mar territorial e nas águas interiores. Em linhas gerais, o decreto retomava o critério híbrido de $200 \mathrm{~m}$ de profundidade ou explotabilidade da Convenção sobre a Plataforma Continental (CPC). Segundo seu artigo 3을 a plataforma submarina era a parcela do território nacional, incluída entre os bens da União, que compreendia:

a) o leito do mar e o subsolo das regiões submarinas adjacentes às costas, mas situadas fora do mar territorial, até uma profundidade de 200 metros, conforme representada nas cartas náuticas da Diretoria de Hidrografia e Navegação do Ministério da Marinha, ou além deste limite até o ponto em que a profundidade das águas sobrejacentes permita o aproveitamento dos recursos naturais das referidas regiões; b)o leito do mar e o subsolo das regiões submarinas análogas, que são adjacentes às costas das ilhas.

Em 26 de agosto de 1968, o Decreto no 63.164 revogou aquele diploma e introduziu mudança significativa em relação à plataforma continental, levando 0 país a uma situação de indefinição sobre o bordo externo de sua plataforma.

Em 1970, por meio do Decreto-Lei oㅜ 1.098, o Brasil, de forma unilateral ${ }^{14}$, estabeleceu os limites de seu mar territorial em 200 milhas marítimas, sobre 0 qual exerceria plena soberania nas águas, no leito, no subsolo e no espaço aéreo sobrejacente, tendo como principal finalidade os aspectos econômicos, com ênfase para as atividades pesqueiras.

Em 1971, através do Decreto o 68.459, estabeleceu duas zonas de pesca, de 100 milhas marítimas cada uma, sendo a primeira para a pesca por brasileiros e a segunda por estrangeiros, devidamente autorizados pelo Governo Federal.

\footnotetext{
${ }^{14}$ Destaca-se que houve protesto internacional, pois se tratava de um ato unilateral. Em 1972, os Estados Unidos assinaram um acordo de pesca com o Brasil, reconhecendo sobre aquela área, soberania brasileira (BEIRÃO; PEREIRA, 2014).
} 
O Brasil ratificou a CNUDM em 22 de dezembro de 1988, quando, oficialmente, incorporou a zona econômica exclusiva (de 200 milhas náuticas, uma área oceânica de 3,5 milhões de $\mathrm{km}^{2}$ ). Com a finalidade de tornar os limites marítimos compatíveis com a Convenção de Montego Bay, que definia apenas 12 milhas marítimas, o Brasil promulgou a Lei oㅜ 8.617/1993.

Para o Brasil, o Decreto n 1.530/1995, declarou a entrada em vigor da Convenção a partir de 16 de novembro de 1994, conforme ratificado em 22 de dezembro de 1988. Beirão e Pereira (2014) destacam que, antes da entrada em vigor da Convenção, porém em adequação a ela, o mar territorial brasileiro de 200 Milhas Náuticas (MN) foi substituído por um mar territorial de apenas $12 \mathrm{MN}$, sendo esse o limite defendido historicamente pela ONU.

Cabe observar que inicialmente, a III Conferência das Nações Unidas sobre o Direito do Mar (1982), herdou a estrutura básica do Comitê dos Fundos Marinhos e foi dividida em três Comissões negociadoras. Segundo Machado (2015), a I Comissão foi encarregada de formatar o conceito de patrimônio comum da humanidade, ao tratar do regime dos fundos marinhos além das jurisdições nacionais, assim como do aproveitamento de seus recursos. A II Comissão tratou dos temas clássicos do Direito do Mar, que inclui os regimes do mar territorial, da zona contígua, do que posteriormente passou a ser zona econômica exclusiva, assim como, do alto mar e da plataforma continental. Por fim, a III Comissão tratou da proteção do meio ambiente marinho e do regime de pesquisa científica.

Com a conclusão dos trabalhos da III CNUDM, o Governo brasileiro defrontou-se com a decisão de assinar ou não uma convenção internacional pela qual se limitaria a doze milhas a extensão do mar territorial propriamente dito. Também reconheceriam os direitos soberanos e a jurisdição do estado costeiro uma zona econômica exclusiva até duzentas milhas de seu litoral e, mais além, sobre o solo e o subsolo do fundo do mar até o seu limite exterior da margem continental (CASTRO, 1989).

A CNUDM, "foi o maior e mais bem sucedido esforço de codificação do direito internacional da história, em um dos campos mais tradicionais da convivência entre as nações". No que se refere ao Brasil, a negociação envolveu uma geração de diplomatas, juristas e técnicos, que tiveram uma participação relevante na elaboração do novo Direito do Mar (MACHADO, 2015, p. 50).

O regime jurídico da plataforma continental foi consolidado na III CNUDM, em sua Parte VI nos artigos de 76 a 85. Cabe destacar que a participação do Brasil foi uma das mais ativas na II Comissão, fato reconhecido por diversos autores, já que tratava de garantir os direitos sobre as 200 milhas ao longo da costa brasileira, em especial no que se refere a garantia dos direitos brasileiros 
ao mar das 200 milhas, conforme declarado no Decreto-Lei no 1.098/1970 do mar territorial. Mesmo que de forma discreta, a participação do Brasil foi considerada muito eficaz. Para Machado (2015), pode-se dizer que o papel do Brasil ${ }^{15}$ foi fundamental no processo de elaboração do novo Direito do Mar, tanto no contexto latino-americano e no plano internacional.

A CNUDM atribui ao Estado costeiro, em seu artigo 77, "direitos de soberania sobre a plataforma continental para efeitos de exploração e aproveitamento de seus recursos naturais" (CNUDM, 1982). Cabe observar a coincidência entre a posição sustentada pelo Brasil, desde o início do processo negociador na II Comissão, e a solução final adotada pela Conferência em 1980. O objetivo brasileiro era garantir direitos sobre a maior extensão possível de plataforma continental durante as negociações da III Conferência das Nações Unidas sobre o Direito do Mar, o que permanece até hoje.

Para Jete Fiorati (1997) a CNUDM passou a refletir os grandes embates do mundo contemporâneo, como, por exemplo, o conflito Norte-Sul, tendo este se tornado maior com o aumento das disparidades econômicas e sociais. Tal pensamento vem ao encontro do que propugna Moniz Bandeira em relação ao posicionamento do Brasil frente suas Forças Armadas. Para Bandeira (2009), é possível vislumbrar situação de conflito no Atlântico Sul, o que tornaria inevitável o envolvimento do Brasil. Assim, para poder atuar na segurança regional e garantir a própria capacidade de defesa, é mister "reequipar e modernizar suas Forças Armadas, particularmente a Marinha de Guerra" (BANDEIRA, 2009, p. 75).

\section{O PROSUB E O PODER NAVAL BRASILEIRO}

Em artigo escrito no início dos anos 1980, o Almirante brasileiro Armando Amorim Ferreira Vidigal distingue três fases ${ }^{16}$. A primeira fase é identificada entre a Independência e o ano de 1893, quando acontece a Revolta da Armada; a segunda, data de 1893 a 1977, quando da denúncia do Acordo Militar Brasil-

\footnotetext{
${ }^{15} \mathrm{O}$ Itamaraty tem uma forte tradição na área do direito do mar, o próprio Ministro de Estado das Relações Exteriores, Embaixador Luiz Alberto Figueiredo Machado, é considerado parte dela. Personalidades como José Sette Câmara, Carlos Calero Rodrigues e Ramiro Saraiva Guerreiro ajudaram a estabelecê-la. Como Representante Permanente em Genebra, Secretário-Geral das Relações Exteriores (1974-1978) e Ministro das Relações Exteriores (1979-1985), Saraiva Guerreiro é reconhecido como um dos principais formuladores e executores da política externa brasileira no setor e também o principal negociador brasileiro da Convenção do Mar, juntamente com o Embaixador Calero Rodrigues (BEIRÃO; PEREIRA, 2014, p. 89).

${ }^{16}$ Quando da publicação original do artigo "A Evolução do Pensamento Estratégico Brasileiro", em 1983, na Revista Marítima Brasileira, o autor era Vice-Almirante. CF. : Revista Marítima Brasileira, V. 138, Suplemento, 2018, p. 47.
} 
Estados Unidos. A terceira, iniciada em 1977 e estendida até então, faz o Brasil reorientar suas concepções à luz de interesses nacionais específicos, o que motiva a Marinha a reformular sua conceituação estratégica.

Esta se traduz nas Políticas Básicas e Diretrizes de 1977 e, posteriormente, no Plano Estratégico da Marinha (PEM). Importante registrar que é a partir desse marco que a Marinha formaliza documentalmente sua concepção estratégica, nos dizeres de Vidigal, "decorrente da política governamental e estrategicamente vinculada à realidade nacional". Citando Terezinha de Castro, o Almirante faz menção à Oceanopolítica e à importância do mar como elemento conformador da estratégia dos povos em geral, e o caso brasileiro, em particular, no sentido da procura de caminhos próprios, que atendam à aspirações e interesses nacionais.

Nesse início de século XXI, quando se desenha a última fronteira do Brasil - fronteira marítima -, a Política Naval, que orienta o planejamento estratégico da Marinha do Brasil, trata da necessidade fundamental de o Brasil dispor de Forças Armadas capazes de garantir a soberania e os interesses estratégicos, no sentido de respaldar a própria política externa. Assim se insere o emprego do Poder Naval. O Documento chama a atenção para ações que assegurem os interesses nacionais no ambiente internacional, "contexto em que o Poder Militar pode ser mais atuante" (BRASIL, Política Naval, 2019, p. 12).

A Amazônia Azul recebe atenção, diante do elevado potencial de recursos vivos e não vivos. De igual modo, a questão dos investimentos em áreas como Ciência, Tecnologia é tratada, no sentido da compreensão de que a insuficiência destes pode impactar na capacidade de garantir a soberania nacional. Também a capacidade dissuasória recebe atenção, questão essa tida como imprescindível, ao lado da capacidade de exercício pleno da soberania. 0 fortalecimento do Poder Naval é definido como um ponto chave, no âmbito da intensificação de disputas por áreas marítimas. Cabe destacar o caráter prioritário que a Política Naval dedica ao PROSUB, o Programa de Desenvolvimento de Submarinos.

O Programa de Desenvolvimento de Submarinos (PROSUB), se insere no âmbito do investimento da Marinha do Brasil na expansão da força naval, e, vale dizer, também no desenvolvimento da indústria de defesa. Foi estabelecido na END 2008 que o Brasil tivesse "força naval de envergadura", que incluísse submarinos com propulsão nuclear. Assim, em 2008, o Brasil firmou com a França um acorde de transferência de tecnologia. A parceria viabilizará a construção de 4 submarinos convencionais, os quais se somarão à frota de cinco submarinos já existentes. O Programa culminará na fabricação do primeiro submarino brasileiro com propulsão nuclear. Daqueles quatro convencionais, um 
foi lançado em dezembro de 2018, o Submarino Riachuelo. Os outros três são o Humaitá, programado para ser lançado em 2020; o Tonelero, em 2021e o Angostura, 2022. O nuclear, Submarino Álvaro Alberto, tem previsão de lançamento para 2029.

O PROSUB foi criado com o objetivo de ampliar a estrutura nacional de defesa. Além disso, o Brasil se consolidará como construtor de submarinos convencionais e se estabelecerá no restrito grupo dos países que constroem e operam submarinos com propulsão nuclear, do qual fazem parte apenas Estados Unidos, Reino Unido, Rússia, França e China. Toda a tecnologia nuclear para o PROSUB está sendo desenvolvida no Brasil, por meio do Programa Nuclear da Marinha (PMN).

O PROSUB também estabelece a construção de um complexo de infraestrutura naval, que envolve o Estaleiro e a Base Naval (EBN) e a Unidade de Fabricação de Estruturas Metálicas (UFEM) (MAQRINHA DO BRASIL, 2019).

As restrições orçamentárias, no entanto, tão comuns à realidade brasileira em diversas áreas de inegável importância, como saúde, educação, também atinge a área da defesa. Para ficar em apenas um exemplo, bloqueio orçamentário da ordem de 32\%, em 2017, colocou em risco a meta do PROSUB de lançar ao mar em 2018 o primeiro submarino. Devido a contingenciamentos anuais desde o lançamento, o PROSUB passou por várias adaptações ${ }^{17}$.

Indubitavelmente, cortes no orçamento para a área da Defesa vão de encontro à proposta e à necessidade de fortalecimento do Poder Naval. Tratase de um problema grave, que precisa ser solucionado, porquanto coloca em xeque os objetivos de Defesa nacionais. É preciso que se transponha o nível do planejamento, da conjectura, e se chegue à prática, à ação. Há que se realizar o efetivo investimento financeiro no reequipamento da das Forças Armadas em geral, e da Marinha, em particular. A plena capacidade dissuasória, presente na essência da identidade e na perspectiva de atuação das Forças brasileiras, não pode mais prescindir dos investimentos devidos. Sob essa perspectiva, cumpre sublinhar que a busca de regularidade orçamentária-financeira consta da Concepção da Política Naval Brasileira.

Cabe destacar a importância, cada vez maior, de se fortalecer o Poder Naval tendo em vista o pleito relativo à plataforma continental estendida (PCE) para a Margem Oriental e Meridional (submissão parcial revisada em dezembro de 2018), que incluiu a Elevação do Rio Grande (ERG). Essa região - ERG - tem

${ }^{17}$ RIBEIRO, Jeferson. "PROSUB - Submarino pode afundar antes de ser batizado". Disponível em: www.defesanet.com.br. Consulta em: 27.03.2019. 
despertado interesse internacional e muitos países vêm promovendo expedições exploratórias na área, com interesses econômicos. Da mesma forma vêm ocorrendo com instituições e empresas estrangeiras, que junto a organismos internacionais buscam a implementação de planos de manejo do Oceano Atlântico com a identificação de áreas marinhas internacionais a serem protegidas, dentre as quais, toda a área da ERG.

Observa-se ainda que a Comissão Europeia lançou programas de Manejo do Atlântico Sul, sem a participação do Estado brasileiro, e edital específico para exploração da Elevação do Rio Grande. Em 2017, o Reino Unido lançou um projeto voltado à Elevação do Rio Grande denominado "e-marine Tech", que agrega inclusive universidades e pesquisadores brasileiros, além de empresas privadas inglesas, que está a evantar dados que subsidiarão um futuro contrato daquele país com a Autoridade Internacional para os Fundos Marinhos $\left(\right.$ ISA) ${ }^{18}$ (SOUZA, 2018).

Em 2018, a Rússia enviou um navio de pesquisa para a região. Da mesma forma Alemanha, China e Reino Unido possuem expedições programadas para estudar as riquezas da região. Os Estados Unidos também já possuem estudos e programaram expedições para explorar a ERG, assim como alguns de seus Institutos de pesquisa têm financiado projetos de exploração da ERG nos últimos anos (SOUZA, 2018). Sendo assim, é possível constatar que “a Elevação do Rio Grande é objeto de uma 'corrida do ouro' sobre riquezas incalculáveis e, por isso, imprescindíveis de avaliação estratégica pelo Brasil" (SOUZA, 2018, p. 7).

Sendo assim, é possível constatar que "a Elevação do Rio Grande é objeto de uma 'corrida do ouro' sobre riquezas incalculáveis e, por isso, imprescindíveis de avaliação estratégica pelo Brasil" (SOUZA, 2018, p. 7).

Recentemente, em 22 de julho de 2020, em reunião realizada entre 0 Serviço Geológico do Brasil (SGB-CPRM) e a Marinha do Brasil, foram discutidos novos projetos conjuntos para impulsionar conhecimento sobre os recursos marinhos do país. Nessa reunião o Almirante de Esquadra Marcelo Francisco Campos apresentou a preocupação com a presença de outros países no Atlântico Sul, com interesses ligados às riquezas marinhas brasileiras, e destacou as várias áreas em torno da Amazônia Azul com domínio do Reino Unido. Esse cenário oceanopolítico envolve também a ERG - fronteira marítima oriental que também se encontra cercada por ilhas estrangeiras. Sendo assim,

\footnotetext{
${ }^{18}$ Autoridade Internacional para os Fundos Marinhos (International Seabed Authority-ISA), organismo da Organização das Nações Unidas responsável por regular e controlar as atividades nos oceanos, fundos marinhos e subsolo das águas internacionais. Ver: https://www.isa.org.jm/.
} 
torna-se estratégico o reconhecimento internacional da margem continental brasileira (SGB-CPRM, 2020).

Para Elcio de Sá Freitas (2018), o Brasil, dispõe de apenas 40 anos, período que denomina de futuro próximo, para se desenvolver e fortalecer. Tratase do período ainda restante para se resguardar a soberania, o patrimônio e a integridade territorial, o que demandará a eliminação da disparidade entre a grandeza potencial e real do País. Aponta Freitas que conseguir investimentos contínuos e vultosos é o maior obstáculo a ser vencido, sendo indispensável que os investimentos em defesa se apliquem no desenvolvimento, e vice-versa. Isso se dá, no entendimento do autor, pelo fato de ser vulnerável o desenvolvimento sem defesa, e insustentável, a defesa forte sem desenvolvimento.

No mesmo diapasão da escassez de recursos, e tendo por foco a renovação do Poder Naval, Eduardo Ítalo Pesce questiona o que se pode fazer para se superar os sucessivos ciclos de decadência e recuperação em que, segundo seu entendimento, a Marinha Brasileira parece estar aprisionada $\left(\right.$ PESCE, 2018) ${ }^{19}$. Na análise do autor, o atraso cíclico figura como provável obstáculo principal à renovação do Poder Naval Brasileiro, o que caracteriza fenômeno antigo e persistente. No entanto, os atrasos e a falta de recursos não interromperam o PROSUB, no âmbito do qual o submarino de propulsão nuclear prevê desenvolvimento de tecnologia nacional e independente.

Ainda assim, dialogando com Pesce (2018), é inescapável inferir ser a Emenda ํㅜ 95/2016, que estabelece teto para o aumento das despesas públicas, bastante prejudicial à Defesa no Brasil em geral e ao PROSUB em particular. Mesmo porque, o PROSUB é fator principal para o reforço do Poder Naval brasileiro, tendo sido estabelecida prioridade inicial aos submarinos. Atrasos neste Programa, além de tornarem mais caro o projeto, podem redundar em perda de credibilidade dissuasória. Isto fragiliza não só politicamente o País na arena internacional, mas também, internamente, a essência da atuação no campo da Defesa, porquanto a dissuasão configura o potencial da ação das Forças Armadas brasileiras, conforme disposto nos Documentos de Defesa. $O$ discurso nos Documentos não deve se distanciar da prática do efetivo fortalecimento do poder militar.

Há que se concordar com Pesce (2018) quanto a ser necessário que o Brasil solidifique sua posição de potência média antes de buscar torna-se uma grande potência. Se aquele indica o dever de se compatibilizar a renovação dos

\footnotetext{
${ }^{19}$ A ênfase da análise de Eduardo Ítalo Pesce não recai sobre o PROSUB, e sim sobre o processo de obtenção de navios aeródromos (NAe) e outros tipos de navio de superfície. No entanto, o autor faz referência aos 21 submarinos ( 15 convencionais e 6 de propulsão nuclear) inseridos no âmbito do PAEMB - Plano de Articulação e Equipamento da Marinha, de 2009. O PROSUB também recebe menção na análise de Pesce.
} 
meios que integram o Poder Naval do País, em ambiente de austeridade e escassez de recursos, sublinha-se, de igual modo, ser necessário, mesmo imprescindível a decisão política de se definir qual estatura de Poder Naval o Brasil efetivamente deseja alcançar, e fazer as escolhas necessárias para tanto. Provavelmente, os recursos disponíveis estarão sempre aquém do desejado, o que não deve impedir o Estado brasileiro de envidar os esforços para atingir as metas estabelecidas, a partir de escolhas criteriosas e realistas, consoantes ao próprio Poder Naval que se queira desenvolver.

\section{CONCLUSÃO}

O respeito ao Direito Internacional e mesmo o recorrer a este Direito é parte da identidade e da história brasileiras, como a própria construção da última fronteira do País exemplifica. De igual modo, os Documentos de Defesa, quais sejam, a END e a PND, valorizam essa prática. Nesse sentido, na própria Concepção de Defesa da PND, dispõe-se sobre o repúdio à intervenção na soberania dos Estados, bem como sobre a ação sempre respaldada nos ditames do ordenamento jurídico internacional. Outrossim, a própria Política Naval Brasileira, no que diz respeito à Concepção da Política Naval, estabelece entre os pressupostos básicos, a atuação sob a égide de organismos internacionais, no sentido de se agir com legitimidade e respaldo jurídico internacional. Assim, a continuidade no cultivo ao Direito Internacional mostra-se benéfica à ação internacional brasileira. Trata-se de atitude política útil para a atuação externa e positiva para as relações interestatais como um todo, em se considerando que a previsibilidade do comportamento de atores de estatura significativa como o Brasil potencialmente contribui para a manutenção da ordem internacional

No entanto, há que se reconhecer ter chegado o momento em que se torna necessário conjugar o Direito e a Força, o que encontra perfeita consonância com o caráter dissuasório da Defesa. Estabelece a Política Naval que se deve manter a Força adequadamente motivada para prover a "adequada capacidade de dissuasão" (Marinha do Brasil, Política Naval, 2018, p. 20). O Documento sublinha que mesmo a cooperação naval internacional deve ser realizada sem prejuízo da dissuasão, diretriz que se repete na PND 2016, quando esta igualmente estabelece como um dos posicionamentos o dever de: "sem prejuízo da dissuasão, privilegiar a cooperação no âmbito internacional e a integração com os países sul-americanos, visando encontrar soluções integradas para questões de interesses comuns ou afins" (Política Nacional de Defesa, 2016, p. 11). 
Este artigo apresenta o quanto vem sendo cuidadoso e complexo o processo de construção da última fronteira brasileira no âmbito da ONU. Pouco falta para que o pleito relativo à Amazônia Azul seja aceito definitivamente em sua inteireza, ou seja, uma área oceânica de cerca de 5,7 milhões de $\mathrm{km}^{2}$ sob jurisdição brasileira. Assim, podemos simplificar e afirmar, sem desconsiderar os estudos e os esforços no âmbito da LEPLAC, que o Direito Internacional concedeu ao Brasil a Amazônia Azul. Mas o Estado brasileiro, dentro do que propõe o conceito de oceanopolítica, precisa estabelecer e implementar medidas que garantam a soberania sobre essa região. Sob essa perspectiva, inegável é a necessidade de se fortalecer o Poder Naval brasileiro, de modo que o País efetivamente venha a ser capaz de atuar militarmente no mar, em defesa das riquezas lá existentes, para que sejam utilizadas para o desenvolvimento nacional. Desta forma, como item principal do fortalecimento do Poder Naval brasileiro, o PROSUB precisa ser concluído. O Brasil precisa decidir que Marinha deseja ter em sentido de magnitude do Poder Naval. Isto certamente se refletirá na própria estatura internacional do País, no apoio à política externa a se executar.

Um novo século ainda se abre; uma nova ordem está em construção, e o Brasil precisa definir que papel exercerá nessa nova ordem. Nela, o conflito permanece uma possibilidade e o País deve estar preparado para defender seus interesses, inclusive respaldado militarmente. Se escassos são os recursos para o investimento em poder militar, altos serão os custos caso se perca o trem da história, a saber, essa janela de apenas quarenta anos sobre o que nos fala Elcio de Sá Freitas. Há escolhas e definições a serem feitas. Assim, sublinhamos: é fundamental, indispensável e inadiável fortalecer o Poder Naval brasileiro. A Amazônia Azul, hoje uma realidade em construção no âmbito da ONU, aponta para possíveis identidades a serem assumidas pelo Brasil do século XXI. Desejável é que o País assuma identidade de um ator estatal ativo, daquele que pode contribuir para com a feitura das regras e normas internacionais; não apenas de seguidor submisso daquelas, inclusive no campo da segurança internacional; daquele capaz de prover a própria segurança e soberania. Lembrando as palavras do Barão, defendemos que o Brasil deve continuar pacífico, mas precisa tornar-se militarmente forte. Nesse sentido, o PROSUB representa a vertente de poder militar que, conjugada ao poder político representado pelo Direito Internacional, é compatível à potência média que é o Brasil hoje, e que melhor pode ser no futuro que se apresenta. 


\section{REFERÊNCIAS}

BANDEIRA, Luiz Alberto Moniz. Geopolítica e Política Exterior: Estados Unidos, Brasil e América do Sul. Brasília, FUNAG, 2009.

BARBOSA Jr., Ilques. "Oceanopolítica: uma pesquisa preliminar". In: Revista Marítima Brasileira. Vol. 129, n. 04/06, abr./jun. 2009.

BEIRÃO, André Panno; PEREIRA, Antônio Celso Alves (organizadores). Reflexões sobre a Convenção do Direito do Mar. Brasília: FUNAG, 2014.

BOBBIO, Norberto; MATTEUCCI, Nicola; PASQUINO, Gianfranco. Dicionário de Política. Vol. 2. Rio de Janeiro: Campus, 1992.

BRASIL. Estado-Maior da Armada. EMA 322. O Posicionamento da Marinha do Brasil nos Principais Assuntos de Interesse Naval. (2ª Revisão). Brasília, 2017.

BRASIL. MARINHA DO BRASIL. Estado-Maior da Armada. EMA 305. Doutrina Básica da Marinha. (2ª Revisão), Brasília, 2014.

BRASIL. MARINHA DO BRASIL. O que é a Amazônia Azul e por que o Brasil quer se tornar potência militar no Atlântico-2019. Disponível em: https://www.marinha.mil.br/economia-azul/noticias/o-que-\%C3\%A9-

amaz\%C3\%B4nia-azul-e-por-que-o-brasil-quer-se-tornar-pot\%C3\%AAnciamilitar-no-atl\%C3\%A2ntico. Acesso em: 28 jul. 2020.

BRASIL. MINISTÉRIO DA DEFESA. Política Nacional de Defesa / Estratégia Nacional de Defesa. Brasília, 2012.

BUSCH, Jorge Martinez. La Oceanopolítica: una alternativa para el desarrollo. Santiago, Chile: Andres Bello, 1993.

CASTRO, de ARAUJO Luiz Augusto. O Brasil e o novo Direito do Mar: mar territorial e zona econômica exclusiva. Brasília: Fundação Alexandre de Gusmão, 1989 - (Ministério das Relações Exteriores, Instituto Rio Branco).

CERVO, A. L.; BERVIAN, P. A. Metodologia científica. São Paulo: Prentice Hall, 2002.

COMISSÃO INTERMINISTERIAL PARA OS RECURSOS DO MAR. VIII PLANO SETORIAL PARA OS RECURSOS DO MAR - 2012-2015. Disponível em: https://www.marinha.mil.br/secirm/sites/www.marinha.mil.br.secirm/files/resoluc ao-6-2011-anexo1.pdf. Acesso em: 24 mar. 2019.

COMMISSION ON THE LIMITS OF THE CONTINENTAL SHELF - CLCS. Executive Summary. Continental Shelf and UNCLOS Article 76. Brasilian partial revised submission to the Commission on the Limits of the Continental Shelf. Brazilian Equatorial Margin 2017.

COMMISSION ON THE LIMITS OF THE CONTINENTAL SHELF - CLCS. Executive Summary. Continental Shelf and UNCLOS Article 76. Brasilian partial revised submission to the Commission on the Limits of the Continental Shelf. 
Universidade Federal Fluminense

Instituto de Estudos Estratégicos

Brazilian Oriental and Meridional Margin 2018. Disponível em: https://www.un.org/Depts/los/clcs_new/clcs_home.htm. Acesso em: 8 dez. 2018.

CONVENÇÃO DAS NAÇÕES UNIDAS SOBRE O DIREITO DO MAR - CNDUM. Disponível em: http://www.fd.uc.pt/Cl/CEE/OI/ISA/convencao_NU_direito_marPT.htm. Acesso em: 06 mai. 2019.

FIGUEIRÔA, Christiano Sávio Barros. Limites exteriores da plataforma continental do Brasil conforme o direito do mar. Brasília: FUNAG, 2014. 381 p. (Coleção CAE).

FIORATI, Jete Jane. "A Convenção das Nações Unidas sobre Direito do Mar de 1982 e os organismos internacionais por ela criados". In: Revista de Informação Legislativa, Vol. 34, n. 133, p. 129-154, jan./mar. De 1997.

FONSECA Jr., Gelson. A Legitimidade e Outras Questões Internacionais: poder e ética entre as nações. São Paulo: Paz e Terra, 1998.

FRANÇA, Tereza Cristina Nascimento. "Nas águas das relações internacionais: o oceano como meio, teatro e objetivo dos estados". In: BARBOSA Jr., Ilques; MORE, Rodrigo Fernandes. Amazônia Azul: política, estratégia e direito para o oceano do Brasil. Rio de Janeiro: Femar, 2012.

FREITAS, Elcio de Sá. "Poder Naval - presente e futuro (Parte 3)". In: Revista Marítima Brasileira, Vol. 138, n.10/12, out/dez 2018.

GARTZKE, Erik. The Relevance of Power in International Relations. Disponível em: https://bc.sas.upenn.edu/system/files/Gartzke_03.04.10.pdf. Acesso em: 08.05.12

GIL, Antlõnio C. Métodos e técnicas de pesquisa social. São Paulo: Atlas, 1999.

GONÇALVES, Alcindo; GRANZIERA, Maria Luiza Machado. "Amazônia Azul e governança". In: BARBOSA Jr., Ilques; MORE, Rodrigo Fernandes. Amazônia Azul: política, estratégia e direito para o oceano do Brasil. Rio de Janeiro: Femar, 2012.

LAFER, Celso. A Identidade Internacional do Brasil e a Política Externa Brasileira: passado, presente e futuro. São Paulo, Perspectiva, 2001.

LIMA, Maria Regina Soares de; HIRST, Monica. Brasil, Índia e África do Sul: desafios e oportunidades para novas parcerias. São Paulo: Paz e Terra, 2009.

MACHADO, Luiz Alberto Figueiredo. A plataforma continental brasileira e 0 direito do mar: considerações para uma ação política. Brasília: FUNAG, 2015 (Coleção CAE).

MARCONI, M. A.; LAKATOS, E. M. Fundamentos de metodologia científica. São Paulo: Editora Atlas, 2010.

MARINHA DO BRASIL. DIRETORIA DE HIDROGRAFIA E NAVEGAÇÃO. LEPLAC - Plano de Levantamento da Plataforma Continental Brasileira. Disponível em: <https://www.mar.mil.br/dhn. Acesso em 28 out. 2018.

MENEZES, Wagner. O Direito do Mar. Brasília: FUNAG, 2015. 
MIYAMOTO, Shiguenoli. "A segurança e a ordem internacional no limiar do novo século". In: OLIVEIRA, Odete Maria de; RI Jr, Arno Dal. Relações Internacionais: interdependência e sociedade global. ljuí: Unijuí, 2003.

MORE, Rodrigo Fernandes; BARBOSA JÚNIOR, llques (Org). Amazônia Azul: política, estratégias e direito para o Oceano do Brasil. Rio de Janeiro: SaG Serv, FEMAR, 2012.

MORE, Rodrigo Fernandes. "Reflexões sobre a formação de um pensamento oceanopolítico brasileiro". In: BARBOSA Jr., Ilques; MORE, Rodrigo Fernandes. Amazônia Azul: política, estratégia e direito para o oceano do Brasil. Rio de Janeiro: Femar, 2012.

MORRIS, Michael A. Ocean Policy and Law: the case of Brazil. Latin American Commercial Law Symposium. v.2, Boston College International and Comparative Law Review, 1979.

NYE Jr., Joseph S. Cooperação e conflito nas relações internacionais. São Paulo: Gente, 2009.

PESCE, Eduardo Italo. "Renovação do Poder Naval: projetar é preciso". In: Revista Marítima Brasileira, Vol. 138, n.10/12, out/dez 2018.

RIBEIRO, Jeferson. "PROSUB - Submarino pode afundar antes de ser batizado". Disponível em: www.defesanet.com.br. Acesso em: 27 mar. 2019.

RODRIGUEZ, Carlos Calero. O Problema do Mar Territorial. REVISTA BRASILEIRA DE POLÍTICA INTERNACIONAL. Ano XIII № 49-50 - Ano: 1970.

SECRETARIA DA COMISSÃO INTERMINISTERIAL PARA OS RECURSOS DO MAR - SECIRM. MARINHA DO BRASIL. Amazônia Azul. Disponível em: https://www.marinha.mil.br/secirm/amazoniaazul. Acesso em: 23 mar. 2019.

SECRETARIA DA COMISSÃO INTERMINISTERIAL PARA OS RECURSOS DO MAR - SECIRM. MARINHA DO BRASIL. Plano de levantamento da plataforma continental brasileira - LEPLAC. Disponível em: https://www.marinha.mil.br/secirm/leplac. Acesso em: 23 mar. 2019.

SERVIÇO GEOLÓGICO DO BRASIL - SGB-CPRM. Serviço Geológico do Brasil e Marinha do Brasil discutem novos projetos conjuntos para impulsionar conhecimento sobre os recursos marinhos do país - 2020. Disponível em: http://www.cprm.gov.br/. Acesso em: 30 jul. 2020.

SILVA, Alexandre Pereira da. O Brasil e o Direito Internacional Do Mar Contemporâneo: Novas Oportunidades e Desafios. São Paulo: Almedina, 2015.

SOUZA, Claudia Maria Rezende. Serviço Geológico do Brasil - SEG-CPRM. Nota Técnica levantamento geológico marinhos da Elevação do Rio Grande, 2018. 
TRINDADE, Antônio Augusto Cançado. "Direito do Mar: indicações para a fixação dos limites laterais marítimos". In BEIRÃO, André Panno; PEREIRA, Antônio Celso Alves (organizadores). Reflexões sobre a Convenção do Direito do Mar. Brasília: FUNAG, 2014, p. 167 - 222.

UNITED NATIONS. Convention on the Law of the Sea. Commission on the Limits of the Continental Shelf. Scientific and Technical Guidelines of the Commission on the Limits of the Continental Shelf. CLCS, 2004. Disponível em: https://www.un.org/Depts/los/clcs new/commission submissions.htm. Acesso em: 12 mar. 2019.

VIDIGAL, Armando Amorim Ferreira et al. Amazônia Azul: o mar que nos pertence. Rio de Janeiro: Record, 2006.

VIDIGAL, Armando Amorim Ferreira. "O Emprego Político do Poder Naval". In: Revista Marítima Brasileira. (Coletânea Vidigal). V.138, Suplemento, 2018.

VIDIGAL, Armando Amorim Ferreira. "A Evolução do Pensamento Estratégico Brasileiro". In: Revista Marítima Brasileira. (Coletânea Vidigal). V.138, Suplemento, 2018. Marítima Brasileira. (Coletânea Vidigal). V.138, Suplemento, 2018.

VIDIGAL, Armando Amorim Ferreira. "Uma Estratégia Naval para o Século XXP". In: Revista Marítima Brasileira. (Coletânea Vidigal). V.138, Suplemento, 2018. 